\title{
ASSESSING THE YIELD STABILITY OF NINETEEN CHICKPEA (CICER ARIETINUM L.) GENOTYPES GROWN UNDER MULTIPLE ENVIRONMENTS IN SOUTH-EASTERN ANATOLIA, TURKEY
}

\author{
KIZILGECI, F. \\ Department of Field Crops, Faculty of Agriculture, Sirnak University, 73300 Idil, Sirnak, Turkey \\ (e-mail: ferhat_kizilgeci@hotmail.com; phone: +90-486-551-3032) \\ (Received 15 ${ }^{\text {th }}$ Aug 2018; accepted $10^{\text {th }}$ Oct 2018)
}

\begin{abstract}
The identification of high performance stable genotypes is essential for increasing sustainable chickpea production in Turkey. Hence, nineteen chickpea genotypes were examined for stability assessment in different environments in Southeastern Anatolia, Turkey. Chickpea genotypes were sown in early spring and planted in the winter. The analysis of variance showed that the genotypes and locations were significantly differed in the majority of the studied characters. The regression coefficient, deviations of the regression coefficients, coefficient of variation, ecovalence and stability variance were calculated for chickpea genotypes. The stability parameters were varied by the planting dates and environments in which the chickpea genotypes were grown. Among the studied chickpea genotypes, genotype 'FLIP98-143C' was considered as high grain yield and low $b$ value and produced the minimum deviation regarding the regression, genotypic variance, coefficient of variation, ecovalence and stability variance. Therefore, the genotype 'FLIP98-143C' may be used as a stable and high yielding variety in the future and also it may be used in future breeding programs to develop good varieties.
\end{abstract}

Keywords: regression coefficient, chickpea, genotype, stability variance, seed yield

\section{Introduction}

Chickpea (Cicer arietinum L.) is one of the major essential legumes used as food and feed which is grown in 10 million hectares in a wide range worldwide. It supports an essential source of vegetable protein and fixes atmospheric nitrogen into the soil (Adeel et al., 2012). It is an essential grain legume crop of Southeastern Anatolia, Turkey, and it is widely grown in rotation with winter cereals. Chickpea is grown both in winter and early/late spring in Turkey (Karakoy, 2012; Dogan et al., 2015), although several genotypes have good yield performance, when they are grown in various planting dates. They produced low yield due to anthracnose (Ascochyta blight) disease and drought stress environment. Therefore, they could show different performances in various environments. Mega environments help to identify the most appropriate cultivars that can be recommended for the relevant areas within the mega-environment in one or more tested locations.

The susceptibility of existing varieties to fluctuations of the environment is a major factor that is responsible for low yield and yield instability (Adeel et al., 2012). Because of the widespread presence of genotype and environment interactions, yield stability has taken much louder voice to develop the dropping yield of crops. There is some vital trait to calculate yield stability (Ludlow and Muchow, 1990; Adeel et al., 2012). The genotypes used in the current study have been high or low yielding in previous years in only one location, but their performances in different environments are very important to be concerned as a new variety for region under investigation (Yadav et al., 2016). Plant breeders have used the stability to produce a genotype that indicates a relatively constant yield, independent of environmental conditions (Sabaghnia et al., 2012). 
The stability traits to identify genotypes with stable performance across different environments (Shafi et al., 2012) according to Eberhart and Russel (1966) methods. Several models for the statistical measurement to evaluate the stability have been reported by research studies (Wricke, 1962; Finlay and Wilkinson, 1963; Eberhart and Russell, 1966; Francis and Kannenberg, 1978), but single method could not adequately explain cultivar performance across environments (Mohebodini et al., 2006). Finlay and Wilkinson (1963) used the coefficient of regression $(b)$ as a stability parameter. They reported the regression coefficients can be used to describe the response of various cultivars to environments. The coefficient of variation (Francis and Kannenberg, 1978) is used to select cultivars that produce both high yield and low variance (a small amongenvironment variance). Wricke's ecovalance (1962) suggested using genotype environment interactions for each genotype as a stability measure. Shukla (1972) used stability variance of genotypes to determine the stability of a genotype. So, keeping these views in mind, the present study was designed to examine the yield stability under different environments and different stability parameters in order to identify chickpea genotypes with stable performance across various environments in Southeastern Anatolia, Turkey.

\section{Materials and methods}

The current research was conducted in Southeast Anatolia, Turkey on chickpea genotypes to compare and identify the most stable and high yielding genotypes during 2015-2016 growing seasons. Experiment was conducted in multiple environments in Southeastern Anatolia, Diyarbakir (altitude: $674 \mathrm{~m}$ ), Silvan (altitude: $840 \mathrm{~m}$ ), Hazro (altitude: $1050 \mathrm{~m}$ ) and Kiziltepe (altitude: $498 \mathrm{~m}$ ), Turkey. Silvan and Hazro are colder and rainier than Diyarbakir and Kiziltepe, and in Kiziltepe due to evaporation plant growth has a shorter period than in other locations (Table 1).

The materials for the present study comprised a total of 19 genotypes of chickpeas (Cicer arietinum L.) tested in a randomized complete block design with four replications. The genotypes including nine hybrid genotypes in $F_{7}$ generation (D2-5, D2-8, D1-3, D2-6, D1-13, D1-14, D1-28, R4 and R6 from crosses Konya $\times$ Balikesir, Konya $\times$ ILC3279, ILC3279 $\times$ Balikesir and Diyar $95 \times$ ILC 482), four ICARDA genotypes (FLIP97-254C, FLIP98-206C, FLIP98-143C and FLIP99-34C) selected from the drought tolerance collection, one local genotype (N5-5 from Diyarbakir chickpea production areas) and Turkish chickpea varieties (Diyar 95, Arda, Azkan, Gokce and Cagatay).

The genotypes were planted in six rows at $4 \mathrm{~m}$ length, with $45 \mathrm{~cm}$ spacing and with a seed rate of 55 seed $\mathrm{m}^{-2}$. Planting was done in winter, planting was performed 27 December, 2014 and 20 November, 2015 in Diyarbakir, and 22 November, 2015 in Kiziltepe. Early spring planting was performed 18 February in Diyarbakir, 15 February in Kiziltepe, 17 February in Hazro, and 19 February in Silvan in the 2016 growing season. Fertilization was applied over $30 \mathrm{~kg} \mathrm{ha}^{-1} \mathrm{~N}$ and $50 \mathrm{~kg} \mathrm{ha}^{-1} \mathrm{P}_{2} \mathrm{O}_{5}$ in planting time. The agronomic and cultural practices prevailing with the local requirements were done at each location. Plants were harvested $5.4 \mathrm{~m}^{2}$, and the treatments were hand harvested at the end of June. Seed yield per plot ( $\mathrm{g}$ ) data were collected from different locations and converted to $\mathrm{kg}$ per hectare $\left(\mathrm{kg} \mathrm{ha}^{-1}\right)$. 
Table 1. Meteorological data of experimental areas. (Source: Turkish State, Meteorological Service/Ankara)

\begin{tabular}{|c|c|c|c|c|c|c|c|c|c|c|c|c|}
\hline & \multicolumn{4}{|c|}{ Average temperature $\left({ }^{\circ} \mathrm{C}\right)$} & \multicolumn{4}{|c|}{ Average humidity (\%) } & \multicolumn{4}{|c|}{ Total precipitation $(\mathbf{m m})$} \\
\hline & Hazro & Silvan & D.bakir & K.tepe & Hazro & Silvan & D.bakir & K.tepe & Hazro & Silvan & D.bakir & K.tepe \\
\hline \multicolumn{13}{|c|}{2015} \\
\hline January & 2.8 & 3.6 & 2.0 & 5.2 & 74.4 & 85.5 & 92 & 64.1 & 138.4 & 95.8 & 66.6 & 60.0 \\
\hline February & 5.0 & 6.4 & 5.0 & 6.7 & 77.2 & 79.7 & 92.5 & 66.8 & 113.8 & 92.5 & 65.8 & 111.0 \\
\hline March & 7.9 & 9.3 & 7.6 & 10.1 & 69.7 & 72.6 & 86.2 & 57.9 & 154.7 & 117.5 & 122.2 & 149.9 \\
\hline April & 11.7 & 13.3 & 12.1 & 14.5 & 67.1 & 68.1 & 79.7 & 51.0 & 82.8 & 66.0 & 42.4 & 46.3 \\
\hline May & 19.0 & 20.5 & 18.9 & 22.5 & 47.9 & 48.4 & 59.2 & 33.4 & 14.5 & 23.8 & 28.5 & 49.7 \\
\hline June & 25.4 & 27.3 & 25.6 & 28.5 & 29.3 & 27.2 & 36.4 & 24.2 & 6.9 & 4.60 & 3.4 & 3.7 \\
\hline Nov. & 10.6 & 11.1 & 9.5 & 10.2 & 54.2 & 62.5 & 62.7 & 53.1 & 22.7 & 13.7 & 9.0 & 95.6 \\
\hline Dec. & 5.3 & 5.9 & 3.8 & 7.5 & 53.3 & 61.0 & 61.6 & 72.2 & 33.8 & 22.2 & 23.2 & 100.4 \\
\hline \multicolumn{13}{|c|}{2016} \\
\hline January & 1.3 & 2.4 & 1.1 & 5.3 & 82.2 & 90.1 & 82.5 & 74.1 & 73.4 & 71.3 & 79.2 & 143.4 \\
\hline February & 7.3 & 8.9 & 7.9 & 11.1 & 72.9 & 75.4 & 75.2 & 67.3 & 74.6 & 76.2 & 62.2 & 68.8 \\
\hline March & 9.0 & 10.5 & 9.7 & 12.0 & 67.6 & 64.7 & 70 & 66.2 & 60.8 & 134.0 & 39.6 & 86.4 \\
\hline April & 15.4 & 19.9 & 15.7 & 17.5 & 50.4 & 51.2 & 59.9 & 58.3 & 40.0 & 52.3 & 18 & 38.5 \\
\hline May & 18.2 & 27.4 & 19.9 & 21.0 & 49 & 51.3 & 56.1 & 53.0 & 45.1 & 52.1 & 38.2 & 21.4 \\
\hline June & 25.1 & 32.2 & 26.8 & 29.1 & 31.4 & 28.6 & 35.1 & 26.5 & 19.2 & 6.0 & 4.2 & 0.0 \\
\hline
\end{tabular}

\section{Stability parameters}

The regression coefficient (bi) was measured according to Finlay and Wilkinson (1963) to determine the stability. According to Eberhart and Russell (1966), the regression coefficients approximating one coupled with $\left(S^{2} d\right)$ of zero indicate average stability. Ecovalence $\left(W^{2} i\right)$ as suggested by Wricke (1962) was calculated to further illustrate stability. The GE interaction effect for genotype i, squared and summed across all environments, is the stability estimated for genotype i. A low ecovalence $\left(W^{2} i\right)$ value indicates high relative stability. An unbiased estimate using stability variance $\left(\sigma^{2} i\right)$ of genotypes was measured according to Shukla (1972). The stability was estimated by combining the use of coefficient of variation $(\mathrm{CV} i)$ and mean yield (Francis and Kannenberg, 1978).

\section{Results and discussion}

The analysis of variance of chickpea genotypes at different locations (Table 2) was significant for seed yield. Variance analysis was performed for each environment, and genotypes and genotypes $\mathrm{x}$ environments interactions were significant for grain yield. Grain yield ranks were given in Table 2. Understanding the nature of genotype and environment interactions is essential in plant breeding programs because a positive significant genotype and environment interaction can extremely impair efforts to identify the superior genotypes related to new crop release and improvement programs (Danyali et al., 2012; Hasan and Deb, 2017). 
Table 2. Grain yield rank over environments on chickpea genotypes

\begin{tabular}{c|c|c|c|c|c|c}
\hline \multirow{2}{*}{ Genotypes } & \multicolumn{3}{|c|}{ Spring planting } & \multicolumn{2}{c}{ Winter planting } \\
\cline { 2 - 7 } & Diyarbakir & Silvan & Hazro & Kiziltepe & Diyarbakir & Kiziltepe \\
\hline D2-5 & 15 & 16 & 9 & 15 & 10 & 9 \\
D2-8 & 18 & 9 & 17 & 8 & 17 & 2 \\
D1-3 & 19 & 7 & 18 & 18 & 5 & 19 \\
D2-6 & 9 & 6 & 7 & 12 & 19 & 12 \\
D1-13 & 13 & 8 & 12 & 14 & 18 & 16 \\
D1-14 & 12 & 13 & 16 & 17 & 15 & 18 \\
D1-28 & 8 & 14 & 15 & 16 & 14 & 15 \\
R4 (ILC 482 x FLIP 83-47C) & 6 & 5 & 11 & 7 & 13 & 6 \\
R6 (FLIP 83-47Cx ILC 482) & 4 & 10 & 10 & 5 & 9 & 4 \\
N5-5 & 7 & 15 & 6 & 6 & 11 & 17 \\
FLIP97-254C & 14 & 3 & 4 & 13 & 1 & 13 \\
FLIP98-206C & 1 & 17 & 3 & 2 & 8 & 7 \\
FLIP98-143C & 2 & 2 & 8 & 3 & 7 & 8 \\
FLIP99-34C & 3 & 1 & 14 & 4 & 2 & 14 \\
Diyar 95 (FLIP 83-47C) & 17 & 19 & 19 & 19 & 12 & 10 \\
Arda & 5 & 4 & 5 & 11 & 3 & 3 \\
Azkan & 16 & 18 & 13 & 9 & 4 & 1 \\
Gokce & 11 & 11 & 1 & 1 & 16 & 11 \\
Cagatay & 10 & 12 & 2 & 10 & 6 & 5 \\
Genotype & $* *$ & $* *$ & $* *$ & $* *$ & $* *$ & $* *$ \\
\hline Genotype* environment & & & $* *$ & & & $* *$ \\
\hline
\end{tabular}

**Significance level at 0.01 probability

The differences among genotypes for yield ranks in all environments were significant, ICARDA originated genotypes, FLIP98-143C, FLIP98-206C and FLIP99$34 \mathrm{C}$, were identified as top genotypes in three environments in early spring planting. D2-5, D2-8, D1-3, D2-6, D1-13, D1-14 and D1-28 had low yield in all locations, due to their parents sensitivity to anthracnose. Late maturing genotypes were exposed to terminal drought in the region, ICARDA genotypes had small seeds, short plant height and early maturing, therefore, these genotypes were more advantageous than other varieties in spring planting. Varieties Arda and Azkan were identified as top cultivars in winter planting, these winter varieties, Arda and Azkan, always had high yielding in winter sowing due to high tolerance to anthracnose (Ascochyta blight). Since Diyar 95 (FLIP 83-47C) had matured later than all other varieties, it had low efficiency at both planting times. Kan et al. (2010) and Erdemci (2012) recorded that when the interaction is significant and rank of genotypes performance changes, genotypes should be bred for each location, and the optimum way is to identify lines that reveal higher performance annually. These findings indicated that these parameters could be used as a substitute for one another in genotypes and environment interactions studies of chickpea. Significant genotype and environment interaction was also recorded by Arshad et al. (2003) and Bakhsh et al. (2006) in chickpea, by Janković et al. (2017) in Phleum pratense (L.) and EL-Shawy et al. (2017) in Barley. Gauch and Zobel (1988) reported 
that, the low variance of genotypic effect could be due to proximity of genetic potential of the examined genotypes.

\section{Regression coefficient and mean yield in chickpea}

The stability performances of the chickpea genotypes for different planting dates summarized for the regression co-efficient $(b)$ and grain yield in Table 3. Grain yield was ranged from $820 \mathrm{~kg} \mathrm{ha}^{-1}$ to $1415.5 \mathrm{~kg} \mathrm{ha}^{-1}$ in early spring planting, from $1252.0 \mathrm{~kg} \mathrm{ha}^{-1}$ to $1989.0 \mathrm{~kg} \mathrm{ha}^{-1}$ mean in winter planting. Some genotypes were produced higher seed yield than some check varieties in spring planting. Regression coefficient $(b)$ values ranged from -1.3 to 3.8 in early spring planting, and it ranged from 0.9 to 2.5 , and stability performance for genotypes varied by planting time and location.

The high $b$ value and high grain yield were estimated for eight genotypes in early spring planting, two genotypes in winter planting. It was estimated that the high regression co-efficient $(b)$ and high grain yield values could be produced with a great number of experimental environment. Genotypes of the group fitted the definition of the ideal cultivar (Eberhart and Russell, 1966; Mart et al., 2005).

Table 3. The regression co-efficient (b) and grain yield in chickpea

\begin{tabular}{c|c|c|c|c}
\hline \multirow{2}{*}{ Genotypes } & \multicolumn{2}{|c|}{ SPRING } & \multicolumn{2}{c}{ Winter } \\
\cline { 2 - 5 } & Yield (kg ha-1 $)$ & b & Yield (kg ha-1 $)$ & b \\
\hline D2-5 & 1088 & 1.1 & 1617 & 0.9 \\
D2-8 & 1062 & -1.3 & 1689 & -0.9 \\
D1-3 & 1002 & -1.0 & 1416 & 2.5 \\
D2-6 & 1237 & 1.3 & 1430 & 0.4 \\
D1-13 & 1156 & 0.9 & 1252 & 1.3 \\
D1-14 & 1079 & 1.2 & 1274 & 1.6 \\
D1-28 & 1118 & 1.7 & 1378 & 1.1 \\
R4 & 1270 & 1.1 & 1567 & 0.4 \\
R6 & 1289 & 1.6 & 1741 & 0.4 \\
N5-5 & 1247 & 1.8 & 1365 & 2.0 \\
FLIP97-254C & 1285 & 0.4 & 1716 & 2.0 \\
FLIP99-34C & 1389 & 0.2 & 1652 & 0.9 \\
FLIP98-143C & 1415 & 1.1 & 1644 & 1.0 \\
FLIP98-206C & 1382 & 3.8 & 1641 & 2.4 \\
Diyar 95 (FLIP 83-47C) & 820 & 0.5 & 1544 & 0.6 \\
Arda & 1316 & 1.5 & 1938 & 0.9 \\
Azkan & 1040 & 0.1 & 1989 & 0.2 \\
Gokce & 1341 & 0.9 & 1469 & 0.5 \\
Cagatay & 1275 & 1.9 & 1744 & 0.8 \\
\hline Mean & 1201 & & 1582 & \\
\hline
\end{tabular}

Three genotypes in spring planting and eighteen genotypes in winter planting had low $b$ value but above average yields. The group quite dominated in the winter varieties. Winter planting is usually produced high yield, but anthracnose disease caused yield fluctuations over the environments. The group has responsive to the good 
environmental conditions (Eberhart and Russell, 1966), therefore, if late winter sowing is applied in these genotypes, high yield can be obtained taking benefit of the mechanism of being avoided by the disease. Varieties Arda, Azkan and Cagatay for winter planting, genotypes FLIP97-254C and FLIP99-34C for both planting date were significant genotypes (Table 3). Stability in the seed yield was earlier reported by several researchers (Abbas et al., 2008; Atta and Shah, 2009).

Five genotypes in spring planting and three genotypes in winter planting had a low $b$ value and below average yields. Azkan had higher yielding in winter planting than in spring planting, Diyar 95 showed poor performance in both planting dates due to late maturing and sensitivity to anthracnose. The group demonstrated a tendency to perform poorly in unfavorable conditions (Eberhart and Russell, 1966). The genotypes of greatest interest would be those with the lowest Pi values, most of which were due to genetic variation (Lin and Binns, 1988).

The stability performances of the chickpea genotypes for all environments are summarized for the regression co-efficient $(b)$ and grain yield in Table 4.

Table 4. Stability parameters of eight environments of chickpea

\begin{tabular}{c|c|c|c|c|c|c|c|c}
\hline No & Genotypes & Yield $\left(\mathbf{k g ~ h a}^{\mathbf{- 1}}\right)$ & $\mathbf{b}$ & $\mathbf{\delta i j}^{\mathbf{2}}$ & $\mathbf{s}^{\mathbf{2}} \mathbf{i}$ & $\mathbf{C V i}$ & $\mathbf{W}^{\mathbf{2}} \mathbf{i}$ & $\mathbf{\sigma}^{\mathbf{i}} \mathbf{~}$ \\
\hline 1 & D2-5 & 1257 & 1.3 & 372057 & 162286 & 32.1 & 375935 & 69.1 \\
2 & D2-8 & 1179 & 0.9 & 1217089 & 226177 & 40.3 & 1247130 & 229.3 \\
3 & D1-3 & 1131 & 1.6 & 893903 & 293017 & 47.9 & 1033625 & 190.1 \\
4 & D2-6 & 1251 & 0.6 & 347671 & 72915 & 21.6 & 402633 & 74.0 \\
5 & D1-13 & 1132 & 0.8 & 547150 & 119494 & 30.5 & 595140 & 109.4 \\
6 & D1-14 & 1079 & 1.1 & 821106 & 195439 & 41.0 & 856249 & 157.5 \\
7 & D1-28 & 1136 & 1.0 & 787111 & 177021 & 37.1 & 766296 & 140.9 \\
8 & R4 & 1439 & 0.6 & 127974 & 41530 & 14.2 & 162182 & 29.8 \\
9 & R6 & 1545 & 0.9 & 264503 & 90093 & 19.4 & 280890 & 51.7 \\
10 & N5-5 & 1268 & 1.0 & 537097 & 141305 & 29.7 & 504197 & 92.7 \\
11 & FLIP97-254C & 1522 & 0.9 & 540129 & 129469 & 23.6 & 507535 & 93.3 \\
12 & FLIP99-34C & 1636 & 0.6 & 895976 & 151244 & 23.8 & 979596 & 180.1 \\
13 & FLIP98-143C & 1564 & 0.7 & 98667 & 45738 & 13.7 & 127859 & 23.5 \\
14 & FLIP98-206C & 1574 & 1.4 & 372322 & 179760 & 26.9 & 476039 & 87.5 \\
15 & Diyar 95 & 1207 & 1.4 & 383498 & 181356 & 35.3 & 494338 & 90.9 \\
16 & Arda & 1698 & 1.3 & 633148 & 199585 & 26.3 & 716542 & 131.8 \\
17 & Azkan & 1559 & 1.5 & 1274112 & 327314 & 36.7 & 1394703 & 256.5 \\
18 & Gokce & 1461 & 0.4 & 264941 & 48181 & 15.0 & 472200 & 86.8 \\
19 & Cagatay & 1538 & 1.1 & 216911 & 109125 & 21.5 & 254471 & 46.8 \\
\hline & Mean & 1377 & & & & & & \\
\hline
\end{tabular}

Mean: mean grain yield; bi: regression coefficient (Finlay and Wilkinson, 1963); CVi: coefficient of variation (Francis and Kannenberg, 1978); $\mathrm{s}^{2} \mathrm{i}$ : genotypic variance; $W^{2} i$ : Wricke's ecovalence (Wricke, 1962); $\sigma^{2}$ i: stability variance (Shukla, 1972); $\delta \mathrm{ij}^{2}$ : deviation from the regression (Eberhard and Russel, 1966)

Stability parameters were evaluated separately (Table 4); Wricke's (1962) stability parameter $W^{2} i$, the genotypes FLIP98-143C with lower ecovalance $\left(W^{2} i\right)$ was considered to be stable. The stability variance $\left(\sigma^{2} i\right)$ indicated that the genotypes FLIP98- 
143C and R4 had the lowest variance across the environments, while the genotype Azkan, D2-8 and D1-3 had the maximum $\sigma^{2} i$. The genotypes FLIP98-143C and R4 were stable while the genotypes Azkan, D2-8 and D1-3 were unstable. The genotypes FLIP98-143C, R4 and Gokce according to Francis and Kannenberg (1978) stability parameter $(\mathrm{CVi})$ were stable genotypes, and these genotypes produced a low $\mathrm{CV} i$ and high yield (Table 4). The correlation among stability estimates of the various models may indicate if more evaluates should be achieved to improve confidence in the estimation of genotypes performances (Mahtabi et al., 2014).

Genotype FLIP98-143C with produced high grain yield and low $b$ value achieved the minimum deviation from the regression $\left(\delta i j^{2}\right)$, genotypic variance, coefficient of variation, ecovalence and stability variance. It was observed that genotype FLIP98$143 \mathrm{C}$ had high yield and $b=1$ value in winter planting, similarly it indicated high yield and $b$ value in early spring planting, therefore, it may be identified as a new line for location under investigation studied in early spring. However, if there is no risk of anthracnose disease, in less rainy environments, it can be suggested for winter planting. Genotype R4, which produced high seed yield and low $b$ value achieved the lowest deviation from the regression, genotypic variance, coefficient of variation, ecovalence and stability variance. Genotype R4 may be recommended if precipitation is sufficient in spring season. According to Asrat et al. (2008), genotypes with high ecovalence mean and large assessed values are appropriate for high input conditions.

\section{Conclusion}

The results of the present study indicated that the chickpea genotypes differed for yield regarding stability. Based on the stability parameters, it was concluded that, genotype 'FLIP98-143C' was considered as high grain yield and low $b$ value and produced the minimum deviation regarding the regression, genotypic variance, coefficient of variation, ecovalence and stability variance. Therefore, the genotype 'FLIP98-143C' may be used to release as a stable and high yielding variety in the future and also may be used in future breeding programs to develop good varieties.

\section{REFERENCES}

[1] Abbas, G., Atta, B. M., Shah, T. M., Sadiq, M. S., Haq, M. A. (2008): Stability analysis for seed yield in mungbean, Vigna radiata L. Wilczek. - Journal of Agricultural Research 46(3): 223-228.

[2] Adeel, S., Ghulam, S., Zahid, A., Talat, M., Ahmad, B., Ijaz, R. N. (2012): Stability analysis of yield and yield components in chickpea (Cicer arietinum L.) genotypes across three rainfed locations of Pakistan. - Pakistan Journal Botany 44: 1705-09.

[3] Arshad, M., Bakhsh, A., Haqqani, A. M., Bashir, M. (2003): Genotype-environment interaction for grain yield in chickpea (Cicer arietinum L.). - Pak. J. Bot. 35(2): 181-186.

[4] Asrat, A., Assefa, T., Birhanu, A., Negash, K., Fisum, A., Fikadu, G., Rezene, Y., Chemeda, F., Mulugeta, A., Chemeda, D. (2008): Adaptation and yield stability of small red beans elite lines in Ethiopia. - International Journal of Plant Breeding and Genetics 2(2): 51-63. 186.

[5] Atta, B. M., Shah, T. M. (2009): Stability analysis of elite chickpea genotypes tested under diverse environments. - Australian Journal of Crop Science 3(5): 249-256. 
[6] Bakhsh, A., Arshad, M., Haqqani, A. M. (2006): Effect of genotype x environment interaction on relationship between grain yield and its components in chickpea [Cicer arietinum (L.)]. - Pakistan Journal of Botany 38(3): 683-690.

[7] Danyali, S. F., Razavi, F., Segherloo, A. E., Dehghani, H., Sabaghpour, S. H. (2012): Yield stability in chickpea (Cicer arietinum L.) and study relationship among the univariate and multivariate stability parameters. - Research in Plant Biology 2(3): 46-61.

[8] Dogan, Y., Ciftci, V., Ekinci, B. (2015): The effect of different sowing densities on the yield and some yield components of chickpea (Cicer arietinum L.) under Mardin Kiziltepe ecological conditions. - Igdir Uni. Journal of the Institute of Science and Technology 5(1): 73-81.

[9] Eberhart, S. A., Russell, W. A. (1966): Stability parameters for comparing varieties. Crop Science 6: 36-40.

[10] Erdemci, I. (2012): Determination of some agricultural and technological traits of different chickpea (Cicer arietinum L.) genotypes in winter and spring sown under Southeast Anatolia region ecological conditions. - PhD Thesis, Cukurova Uni. Institute of Natural and Applied Sciences.

[11] EL-Shawy, E. E., EL Sabagh, A., Mansour, M., Barutcular, C. (2017). A comparative study for drought tolerance and yield stability in different genotypes of barley (Hordeum vulgare L.). - Journal of Experimental Biology and Agricultural Science 5(2): 151-162.

[12] Finlay, K. W., Wilkinson, G. N. (1963): The analysis of adaptation in plant-breeding programme. - Aust. J. Agric. Res. 14: 742-754.

[13] Francis, T. R., Kannenberg, L. W. (1978): Yield stability studies in short-season maize. I. A descriptive method for grouping genotypes. - Can. J. Plant Sci. 58: 1029-1034.

[14] Gauch, H. G., Zobel, R. W. (1988): Predictive and postdictive success of statistical analyses of yield trials. - Theoretical and Applied Genetics 76: 1-10.

[15] Hasan, M. T., Deb, A. C. (2017): Stability analysis of yield and yield components in chickpea (Cicer arietinum 1.). - Horticult Int J. 1(1): 4-14.

[16] Janković, V., Popović, V., Vučković, S., Ikanović, J., Mihailović, V., EL Sabagh, A, Stevanović, P. (2017): Stability of earliness of autochthonous population of Phleum Pratense L. - Agriculture \& Forestry, 63(4): 253-262.

[17] Kan, A., Kaya, M., Gurbuz, A., Sanli, A., Ozcan, K., Ciftci, C. Y. (2010): A study on genotype $\mathrm{x}$ environment interaction in chickpea cultivars grown in arid and semi-arid conditions. - Scientific Research and Essays 5(10): 1164-1171.

[18] Karakoy, T., Erdem, H., Baloch, F. S., Toklu, F., Eker, S., Kilian, B., Ozkan, H. (2012): Diversity of macro- and micronutrients in the seeds of lentil landraces. - The Scientific World Journal. DOI: 10.1100/2012/710412.

[19] Lin, C. S., Binns, M. R. (1988): A method of analyzing cultivar $\times$ location $\times$ year experiments: A new stability parameter. - Theoretical and Applied Genetics 76: 425-430.

[20] Ludlow, M., Muchow, R. C. (1990): A critical evaluation of traits for improving crop yields in water limited environments. - Adv. Agron. 43: 107-153.

[21] Mahtabi, E. L., Farshadfar, E. Z., Jowkar, M. M. (2014): Stability analysis of yield and yield components in chickpea genotypes. - Agri. Commun. 2014(2): 1-8.

[22] Mart, D., Cansaran, E., Karakoy, T. (2005): Determination of genotype x environment interaction and adaptation ability of chickpea in Cukurova region. - VI. Field Crops Congress 5-9 September, Antalya II: 1027-1032.

[23] Mohebodini, M., Dehghani, H., Sabaghpour, S. H. (2006): Stability of performance in lentil genotypes in Iran. - Euphytica 149: 343-352.

[24] Sabaghnia, N., Karimizadeh, R., Mohammadi, M. (2012): Genotype by environment interaction and stability analysis for grain yield of lentil genotypes. - ŽemdirbystèAgriculture 99(3): 305-312.

[25] Shafi, A., Shabbir, Gh., Akram, Z., Mahmood, T., Bakhsh, A. (2012): Stability analysis of yield and yield components in chickpea (Cicer arietinum L.) genotypes across three rainfed locations of Pakistan. - Pak. J. Bot. 44: 1705-1709. 
[26] Shukla, G. K. (1972): Some statistical aspects of partitioning genotype-environmental components of variability. - Heredity 29: 237-245.

[27] Wricke, G. (1962): Uber eine Methode zur Erfassung der ökologischen Streubreite in Eldversuchen. - Z Pflanzenzücht 47: 92-96.

[28] Yadav, N. K., Ghimire, S. K., Sah, B. P., Sarker, A., Shrestha, S. M., Sah, S. K. (2016): Genotype $\mathrm{x}$ environment interaction and stability analysis in lentil. - International J. of Environment, Agriculture and Biotechnology 1(3): 354-361. 